\title{
PROFESIONALISME GURU PENDIDIKAN KEWARGANEGARAAN DALAM IMPLEMENTASI KURIKULUM TINGKAT SATUAN PENDIDIKAN
}

Oleh:

\author{
Rahayu Sehat Widodo*
}

\begin{abstract}
Abstrak
Implementasi KTSP memerlukan sosok seorang guru yang memiliki kemampuan manajerial dan integritas professional yang tinggi, serta demokratis dalam melaksanakan proses pembelajaran di kelas. Guru profesional akan dapat menyelenggarakan proses pembelajaran dan penilaian yang menyenangkan bagi peserta didiknya, sehingga dapat mendorong tumbuhnya kreativitas belajar pada diri peserta didik. Kesiapan guru dalam pelaksanaan kurikulum sangat menentukan minat dan partisipasi peserta didik dalam pembelajaran. Melalui pelaksanaan dan penyusunan kurikulum yang sesuai diharapkan peserta didik tidak hanya dapat memiliki ilmu pengetahuan namun juga memiliki kesan yang mendalam tentang materi pelajaran, sehingga dapat membentuk peserta didik yang cerdas, terampil, dan berkarakter sesuai dengan yang diamanatkan oleh Pancasila dan UUD 1945.
\end{abstract}

Kata Kunci: Profesionalisme guru, Implementasi KTSP

\section{A. Pendahuluan}

Persoalan pendidikan bagi sebuah negara haruslah dipandang sebagai persoalan yang penting, sebab keberhasilan dan kegagalan pendidikan dalam sebuah negara mempunyai pengaruh yang signifikan bagi perkembangan sumberdaya manusia sebagai generasi penerus bangsa. Maka tidak aneh jika ada pernyataan kegagalan pendidikan dalam sebuah negara dapat menyebabkan runtuhnya sebuah negara, sebab generasi sumberdaya manusia sebagai generasi penerus bangsa memiliki sumberdaya manusia yang rendah.

Hal ini sudah banyak disadari oleh negara-negara maju maupun yang sedang berkembang termasuk Indonesia. Kenyataan ini terlihat dari banyaknya dana APBN yang di alokasikan untuk mengembangkan pendidikan. Sedangkan kenyataan lain yang menunjukkan keseriusan pemerintah dalam memajukan dunia pendidikan yaitu adanya penelitian-penelitian guna mencari penyebab gagal atau belum berhasilnya pendidikan di Indonesia. Bahkan setiap ganti pemerintah atau ganti Menteri pemerintah menetapkan kebijakan baru yang dianggapnya mampu memajukan dunia pemdidikan. Dalam upaya meningkatkan mutu pendidikan

* Guru SMAN 1 Permata Kabupaten Bener Meria, Provinsi Aceh 
nasional, pemerintah khususnya melalui Departemen Pendidikan Nasional terus menerus berupaya melakukan berbagai perubahan dan pembaharuan dalam sistem pendidikan nasional, terutama dalam bidang kurikulum. Dimana dalam bidang kurikulum mulai dekade Tahun 2005 sudah mengalami 2 kali perubahan kurikulum dari Kurikulum Berbasis Kompetensi (KBK) ke Kurikulum Tingkat Satuan Pendidikan (KTSP). Dalam mempersiapkan KTSP Dinas Pendidikan daerah harus benar-benar siap menghadapi dan menyongsong pelaksanaan implementasi KTSP tersebut karena sebagian besar kebijakan yang berkaitan dengan implementasi Standar Nasional Pendidikan dilaksanakan oleh sekolah atau daerah. Sekolah harus menyusun kurikulum tingkat satuan pendidikan (KTSP) yang terdiri dari tujuan pendidikan tingkat satuan pendidikan, struktur dan muatan KTSP, kalender pendidikan, dan silabus dengan cara melakukan penjabaran dan penyesuaian Standar Isi yang ditetapkan dengan Permendiknas No. 22 Tahun 2006 dan Standar Kompetensi Lulusan yang ditetapkan dengan Kepmendiknas No. 23 Tahun 2006

Hal ini tentu akan berdampak kepada keprofesionalisme seorang guru dalam menyesuaikan diri untuk menerapkan kurikulum yang telah diberlakukan oleh pemerintah tersebut. Berkaitan dengan pemberlakuan Kurikulum Tingkat Satuan Pendidikan (KTSP) sekolah berkewajiban dan berwenang untuk menyusun kurikulum sendiri yang melibatkan guru, kepala sekolah, kominte sekolah, dan dewan pendidikan setempat. Hal ini sesuai dengan apa yang dikemukakan oleh Mulyasa (2006:8) KTSP merupakan singakatan dari Kurikulum Tingkat Satuan Pendidikan, yang dikembangkan sesuai dengan satuan pendidikan, potensi sekolah/daerah, karakteristik sekolah/daerah, sosial budaya masyarakat setempat, dan karakteristik peserta didik. Dengan demikian tidak menutup kemungkinan masih banyak seorang guru maupun sekolah yang belum mampu untuk menyusun kurikulum tersebut.

Kurikulum KTSP menuntut keprofesionalisme dan kreatifitas seorang guru dalam menyusun model pendidikan yang sesuai dengan kondisi lokal. Sementara itu berkaitan dengan faktor guru masih terdapat anggapan di masyarakat bahwa siapapun dapat mengajar sehingga tidak merasa perlu untuk mendalami ilmu mengajar. Hal ini ada benarnya bagi mereka yang dapat mengajar dengan sendirinya tanpa mempelajarinya. Selain itu sejauh mana pemahaman seorang guru tentu harus memiliki nilai-nilai pedagogi dalam diri mereka. Dengan nilai-nilai pedagogi yang dimiliki seorang guru tentu akan lebih memantapkan keprofesionalismenya sebagai seorang guru. 
Berhubungan dengan pelaksanaan KTSP ini guru adalah merupakan factor yang sangat penting karena mempunyai pengaruh yang besar terhadap proses dan hasil belajar. Tugas guru tidak hanya menyampaikan informasi kepada peserta didik, tetapi lebih dari itu seorang guru harus mampu menjadi fasilitator yang bertugas memberikan kemudahan belajar (facilitate of learning) kepada seluruh peserta didik, agar mereka dapat belajar dalam suasana yang menyenangkan, gembira, penuh semangat, tidak cemas, dan berani mengemukakan pendapat secara terbuka dan demokratis.

\section{B. Pembahasan}

\section{Profesionalisme Guru Kewarganegaraan}

Profesi guru menurut Undang-Undang tentang Guru dan Dosen harus memiliki prinsip-prinsip profesional seperti tercantum pada pasal 5 ayat 1 , yaitu;

"Profesi guru dan dosen merupakan bidang pekerjaan khusus yang memerlukan prinsip-prinsip profesional sebagai berikut:
a) Memiliki bakat, minat, panggilan jiwa dan idealisme
b) Memiliki kualifikasi pendidikan dan latar belakang pendidikan sesuai dengan bidang tugasnya.
c) Memiliki kompetensi yang diperlukan sesuai dengan bidang tugasnya.
d) Mematuhi kode etik profesi.
e) Memiliki hak dan kewajiban dalam melaksanakan tugas.
f) Memperoleh penghasilan yang ditentukan sesuai dengan prestasi kerjanya.
g) Memiliki kesempatan untuk mengembangkan profesinya secara berkelanjutan.
h) Memperoleh perlindungan hukum dalam melaksanakan tugas profesisionalnya.
i) Memiliki organisasi profesi yang berbadan hukum".

Profesionalisme adalah suatu paham yang menciptakan dilakukannya kegiatan-kegiatan kerja tertentu dalam masyarakat, berbekalkan keahlian yang tinggi dan berdasarkan rasa keterpanggilan serta ikrar untuk menerima panggilan tersebut dengan semangat pengabdian serta selalu siap memberikan pertolongan kepada sesama yang tengah dirundung kesulitan ditengah gelapnya kehidupan (Wignjosoebroto, 1999). Dengan demikian seorang profesional jelas harus memiliki profesi tertentu yang diperoleh melalui sebuah proses pendidikan maupun pelatihan yang khusus, dan disamping itu pula ada unsur semangat pengabdian (panggilan profesi) didalam melaksanakan suatu 
kegiatan kerja. Hal ini perlu ditekankan benar untuk membedakannya dengan kerja biasa (occupation) yang semata bertujuan untuk mencari nafkah dan kekayaan materiil duniawi. Lebih lanjut Wignjosoebroto (1999) menjabarkan profesionalisme dalam tiga watak kerja yaitu, pertama bahwa kerja seorang profesional itu beritikad untuk merealisasikan kebajikan demi tegaknya kehormatan profesi yang digeluti, dan oleh karenanya tidak terlalu mementingkan atau mengharapkan imbalan upah materiil; kedua bahwa kerja seorang profesional itu harus dilandasi oleh kemahiran teknis yang berkualitas tinggi yang dicapai melalui proses pendidikan dan/atau pelatihan yang panjang, ekslusif dan berat; ketiga bahwa kerja seorang professional dapat diukur dengan kualitas teknis dan kualitas moral yang harus menundukkan diri pada sebuah mekanisme kontrol berupa kode etik yang dikembangkan dan disepakati bersama didalam sebuah organisasi profesi. Ketiga watak kerja tersebut mencoba menempatkan kaum profesional (kelompok sosial berkeahlian) untuk tetap mempertahankan idealisme yang menyatakan bahwa keahlian profesi adalah merupakan panggilan jiwa yang bukan berorientasi kepada materialistic melainkan suatu pengabdian demi kesejahteraan manusia, walaupun dalam pengamalan profesi tersebut menerima imbalan, yang jelas akan berbeda nilainya dengan pemberian upah yang hanya pantas diterimakan bagi para pekerja upahan saja.

Sebagaimana lazimnya semua mata pelajaran, mata pelajaran Pendidikan Kewarganegaraan memiliki visi, misi, tujuan, dan ruang lingkup isi. Visi mata pelajaran Pendidikan Kewarganegaraan adalah terwujudnya suatu mata pelajaran yang berfungsi sebagai sarana pembinaan watak bangsa (nation and character building) dan pemberdayaan warga negara. Adapun misi mata pelajaran ini adalah membentuk warga negara yang baik, yakni warga negara yang sanggup melaksanakan hak dan kewajibannya dalam kehidupan berbangsa dan bernegara, sesuai dengan Undang-Undang Dasar 1945.

Adapun tujuan mata pelajaran Pendidikan Kewarganegaraan adalah mengembangkan kompetensi sebagai berikut:

1. Memiliki kemampuan berfikir secara rasional, kritis, dan kreatif, sehingga mampu memahami berbagai wacana kewarganegaraan.

2. Memiliki ketrampilan intelektual dan keterampilan berpartisipasi secara demokratis dan bertanggung jawab.

3. Memiliki watak dan kepribadian yang baik, sesuai dengan norma-norma yang berlaku dalam kehidupan bermasyarakat dan bernegara. 
Rumusan tujuan tersebut sejalan dengan aspek-aspek kompetensi yang hendak dikembangkan dalam pembelajaran Pendidikan Kewarganegaraan. Aspek-aspek kompetensi tersebut mencakup pengetahuan kewarganegaraan (civic knowledge), keterampilan kewarganegaraan (civic skills), dan watak atau karakter kewarganegaraan (civic dispositions).

Dengan demikian seorang warga negara pertama-tama perlu memiliki pengetahuan kewarganegaraan yang baik, terutama pengetahuan di bidang politik, hukum, dan moral dalam kehidupan berbangsa dan bernegara. Selanjutnya seorang warganegara diharapkan memiliki keterampilan secara intelektual maupun secara partisipatif dalam kehidupan berbangsa dan negara. Pada akhirnya, pengetahuan dan keterampilannya itu akan membentuk suatu watak atau karakter yang mapan, sehingga menjadi sikap dan kebiasaan hidup sehari-hari. Watak, karakter, sikap atau kebiasaan hidup sehari-hari yang mencerminkan warga negara yang baik itu misalnya sikap religius, toleran, jujur, adil, demokratis, menghargai perbedaan, menghormati hukum, menghormati hak orang lain, memiliki semangat kebangsaan yang kuat, memiliki rasa kesetiakawanan sosial, dan lain-lain.

\section{Kedudukan Kurikulum Dalam Pendidikan}

Pendidikan yang diberikan orang tua kepada anaknya disebut pendidikan informal karena sifat-sifatnya yang tidak formal, tidak memiliki rancangan yang konkret dan ada kalanya juga tidak disadari. Pendidikan tersebut tidak memiliki kurikulum formal dan tertulis. (Sukmadinata, 1997 : 1)

Pendidikan dalam lingkungan sekolah lebih bersifat formal. Guru sebagai pendidik di sekolah telah dipersiapkan secara formal dalam lembaga pendidikan guru. Ia telah mempelajari ilmu, keterampilan, dan seni sebagai guru. Ia juga telah dibina untuk memiliki kepribadian sebagai pendidik. Lebih dari itu mereka juga telah diangkat dan diberi kepercayaan oleh masyarakat untuk menjadi guru, bukan sekedar dengan surat keputusan dari pejabat yang berwenang, bukan sekadar dengan surat keputusan dari pejabat yang berwenang, tetapi juga dengan pengakuan dan penghargaan dari masyarakat. Guru melaksanakan tugasnya sebagai pendidik dengan rencana dan persiapan yang matang. Mereka mengajar dengan tujuan yang jelas, bahan-bahan yang telah disusun secara sistematis dan rinci, dengan cara dan alat-alat yang telah dipilih dan dirancang secara cermat. Di sekolah guru melakukan interaksi pendidikan secara berencana dan sadar. Dalam lingkungan sekolah telah ada kurikulum formal, yang bersifat tertulis. Guru-guru melaksanakan tugas mendidik secara 
formal, karena itu pendidikan yang berlangsung di sekolah sering disebut pendidikan formal.(Sukmadinata,1997:1-2).

Adapun karakteristik pendidikan formal meliputi: (1) pendidikan formal memiliki rancangan pendidikan atau kurikulum tertulis yang tersusun secara sistematis, jelas, dan rinci; (2) dilaksanakan secara formal, terencana, ada yang mengawasi dan menilai; (3) diberikan oleh pendidik atau guru yang memiliki ilmu dan keterampilan khusus dalam bidang pendidikan; (4) interaksi pendidikan pendidikan berlangsung dalam lingkungan tertentu, dengan fasilitas dan alat serta aturan-aturan permainan tertentu pula. (Sukmadinata, 1997: 2).

Dengan demikian rancangan atau kurikulum formal dan tertulis merupakan ciri utama pendidikan di sekolah. Dengan kata lain, kurikulum merupakan syarat mutlak, hal ini berarti bahwa kurikulum merupakan bagian yang tak terpisahkan dari pendidikan atau pengajaran. (Sukmadinata,1997: 3). Untuk itu pengembangan dan penyusunan silabus yang dilakukan oleh guru harus berpedoman pada empat komponen sebagaimana dikemukakan oleh Tyler dalam Miller and Seller (1985) bahwa kurikulum dan perencanaannya (silabus) harus dilihat dari empat komponen utama yaitu: (1) tujuan; (2) isi atau materi pokok; (3) metode atau prosedur; dan (4) evaluasi. Komponen-komponen tersebut tidak bisa berdiri sendiri-sendiri ,dalam pelaksanaannya karena tiap-tiap komponen berhubungan erat dengan komponen lainnya, seperti komponen tujuan bertalian erat dengan komponen bahan pelajaran, proses belajar mengajar dan penilaian. Kesemuanya harus dilaksanakan secara keseluruhan Misalnya tujuannya adalah psikomotor, maka mulai dari pemilihan bahan adalah sesuai dengan tujuannya yaitu psikomotor demikian juga proses belajar mengajar dan penilaiannya juga harus psikomotor. Jadi tidak mungkin tujuan dari suatu pelajaran berbeda dengan komponenkomponen lainnya dalam suatu pengembangan kurikulum. Maka dengan demikian di dalam pengembangan kurikulum apabila ada perubahan atau pengutamaan suatu komponen maka dengan sendirinya akan mempengaruhi keseluruhan kurikulum.

Setiap pendidikan diarahkan pada pencapaian tujuan-tujuan tertentu, apakah berkenaan dengan penguasaan pengetahuan, pengembangan pribadi, kemampuan sosial, ataupun kemampuan bekerja. Untuk menyampaikan bahan pelajaran, ataupun kemampuan-kemampuan tersebut diperlukan metode penyampaian serta alat-alat bantu tertentu. Untuk menilai hasil dan proses pendidikan, juga diperlukan cara-cara dan alat-alat penilaian tertentu pula. Keempat hal tersebut, yaitu tujuan, bahan ajar, 
metode-alat, dan penilaian merupakan komponen-komponen utama kurikulum (Sukmadinata : 1997: 3).

Dengan berpedoman pada kurikulum, interaksi pendidikan antara guru dan siswa berlangsung dalam ruang hampa, tetapi selalu terjadi dalam lingkungan tertentu, yang mencakup antara lain lingkungan fisik, alam, sosial budaya, ekonomi, politik, dan religi. Kurikulum mempunyai kedudukan sentral dalam seluruh proses pendidikan. Kurikulum mengarahkan segala bentuk aktivitas pendidikan demi tercapainya tujuan-tujuan pendidikan. Menurut Mauritz Johnson (1967:130) kurikulum "prescribes (or at least anticipates) the result of instruction". Kurikulum juga merupakan suatu rencana pendidikan memberikan pedoman dan pegangan tentang jenis, lingkup, dan urutan isi, serta proses pendidikan. Di samping kedua fungsi itu, kurikulum juga merupakan suatu bidang studi, yang ditekuni oleh para ahli atau spesialis kurikulum, yang menjadi sumber konsep-konsep atau memberikan landasan-landasan teoritis bagi pengembangan kruikulum berbagai institusi pendidikan.

\section{Implementasi Kurikulum Tingkat Satuan Pendidikan}

Di dalam pelaksanaan KTSP diversifikasi kurikulum sangat dimungkinkan, artinya kurikulum dapat diperluas, diperdalam, dan disesuaikan dengan keragaman kondisi dan kebutuhan baik yang menyangkut kemampuan atau potensi siswa dan lingkungannya. Diversifikasi kurikulum diterapkan dalam upaya untuk menampung tingkat kecerdasan dan kecepatan siswa yang tidak sama. Oleh sebab itu Implementasi KTSP menuntut kemampuan guru kewarganegaraan untuk mengembangkan silabus sesuai dengan kondisi dan kebutuhannya, dan penyusunannya dapat melibatkan instansi yang relevan di daerah setempat, misalnya instansi pemerintah, swasta, perusahaan dan perguruan tingggi.

Sehubungan dengan pengembangan KTSP, guru pendidikan kewarganegaraan dalam meningkatkan kualitas pembelajaran pendidikan kewarganegaraan harus memiliki hal-hal sebagai berikut:

a. Seorang Guru Pendidikan Kewarganegaraan harus mampu menyampaikan keahliannya untuk semua peserta didiknya. Kegiatannya berdasarkan keyakinan bahwa semua peserta didik dapat belajar. Dia akan memperlakukan peserta didiknya sama, namun mengetahui perbedaan peserta didiknya satu dengan yang lainnya, sehingga dapat memperlakukan mereka sama berdasarkan perbedaan yang telah diketahuinya. Dia akan menyesuaikan kegiatannya berdasarkan observasi serta tentang pengetahuannya akan 
minat, kecakapan, kemampuan, ketrampilan, ilmu pengetahuan, lingkungan keluarga serta huungan satu sama lainnya diantara sesama peserta didik. Guru yang berhasil akan memahami bagaimana peserta didik berkembang dan belajar. Dia akan mempergunakan teori kognisi dan intelegensi dalam kegiatannya. Dia sadar bahwa siswanya akan berperilaku sesuai dengan kontek yang dipengaruhi budaya. Dia akan mengembangkan kemampuan kognitif dan menghormati cara peserta didik belajar. Yang sangat penting adalah mendorong self-esteem, motivasi, karakteristik, bertanggung terhadap masyarakat, respek terhadap perbedaan individu, budaya, kepercayaan dan ras dari peserta didiknya.

b. Seorang Guru Pendidikan Kewarganegaraan harus mampu memahami bidang ilmu keahlian yang akan diajarkannya dan menghargai bagaimana pengetahuan tersebut diciptakan, diorganisasikan, dihubungkan dengan ilmu pengetahuan lainnya serta diterapkan dalam dunia nyata. Dengan tidak melupakan kebijaksanaan dari budaya dan disipln ilmu, serta mengembangkan kemampuan menganalisa dari peserta didiknya. Guru yang berhasil akan mengetahui bagaimana cara menyampaikan ilmu keahliannya kepada peserta didik. Mereka akan tahu mana yang sulit diterima oleh peserta didik, sehingga akan menyampaikannya dengan cara yang dapat diterima. Cara mereka mengajar akan memungkinkan bahan ajar diterima peserta didik dengan baik karena mempunyai srategi mengajar yang telah dikembangkannya sesuai dengan kebutuhan peserta didik yang bervariasi untuk memecahkan massalah yang sesuai dengan kemampuan peserta didik.

c. Seorang Guru Pendidikan Kewarganegaraan harus mampu menciptakan, memperkaya, memelihara dan menyesuaikan cara mengajarnya untuk menarik dan memelihara minat peserta didik dalam mempergunakan waktu mengajar sehingga mengajarnya efektif. Mereka juga akan memberikan pertolongan dalam proses belajar dan mengajar kepada peserta didik dan teman sejawatnya. Guru yang berhasil akan tahu cara mana yang tepat yang dapat dilakssanakan sesuai dengan kebutuhan. Mereka juga akan tahu bagaimana mengatur peserta didikagar dapat mencapai tujuan mengajar yang diinginkan serta mereka akan tahu mengarahkan peserta didik untuk sampai pada lingkungan belajar yang menyenangkan. Mereka memahami bagaimana memotivasi peserta didik termasuk bagaimana cara 
mengatasi apabila peserta didik menemui kegagalan. Pengajar yang berhasil akan juga memahami kemajuan peserta didikdalam belajar baik secara perorangan ataupun secara umum dalam kelasnya. Memahami bermacam-macam cara evaluasi untuk mengetahui perkembangan peserta didik serta bagaimana mengkomunikasikan keberhasilan ataupun kegagalan peserta didik kepada orang tua peserta didik.

d. Guru Pendidikan Kewarganegaraan harus mampu menjadikan dirinya sebagi model dari hasil pendidikan yang akan dijadikan contoh oleh peserta didiknya, baik keberhasilan dari ilmu pengetahuannya ataupun cara mengajarnya. Seperti, keingintahuannya, kejujurannya, keramahannya, keterbukaannnya, mau berkorban dalam mengembangkan peserta didik ataupun hal lain yang berkaitan dengan karakteristik pengajar yang lainnya. Guru yang berhasil akan memanfaatkan ilmu tentang perkembangan individu, keahlian dalam bidang ilmu dan mengajarnya, serta tentang peserta didiknya dalam penilaian dan kepercayaannya bahwa cara inilah yang terbaik untuk dilakukann dalam proses mengajar. Untuk keberhasilan proses mengajarnya seorang guru akan selalu memikirkan dan mengembangkan keberhasilan cara mengajarnya serta selalu menghubungkannya dengan kehidupan sehari-hari yang sesuai dengan teori, ide, ataupun faktanya.

e. Guru Pendidikan Kewarganegaraan harus mampu berkontribusi serta bekerja sama dengan teman sejawatnya tentang seluruh kegiatan yang berkaitan dengan proses belajar dan mengajar, seperti : pengembangan kurikulum, pengembangan staf lainnya selain pengajar, ataupun kebijakan lainnya dari seluruh institusi pendidikan. Mereka akan menilai perkembangan institusinya serta sumber lain yang tersedia dalam menunjang perkembangan pendidikan sesuai kebutuhan masing-masing. Pengajar yang berhasil selalu mendapatkan cara yang terbaik dalam berhubungan degan teman sejawatnya untuk produktivitas hasil pendidikan secara menyeluruh.

\section{Penutup}

Implementasi Kurikulum Tingkat Satuan Pendidikan (KTSP) pada tahun 2006 telah dilaksanakan di seluruh sekolah di Indonesia. Sebagai konsekuensinya, komitmen pelaksanaan KTSP tersebut harus dilakukan oleh masing-masing sekolah yang ada di Indonesia sebagai upaya pengembangan sumber daya manusia (human resource). Pengembangan sumber daya manusia (human 
resource) yang dilakukan secara sistematis, pragmatis dan berjenjang. Sebagaiman yang dikemukakan Tilaar (1997:32) Pendidikan pada saat ini dihadapkan pada tuntutan tujuan yang semakin canggih, semakin meningkat baik ragam, lebih-lebih kualitasnya. Agar pendidikan bisa berfungsi dan mencapai tujuan seperti dirumuskan dalam undang-undang tersebut, maka pendidikan harus "diadministrasikan", atau dikelola dengan mengikuti ilmu administrasi. Pengadministrasian dalam pembelajaran salah satunya adalah penyusunan silabus yang disusun oleh setiap guru dalam proses pembelajaran sebagai acuan garis-garis besar materi pelajaran yang akan dijabarkan ke dalam rencana pelaksanaan pembelajaran. Pengembangan dan penyusunan silabus yang dilakukan oleh guru harus berpedoman pada empat komponen sebagaimana dikemukakan oleh Tyler (1994) bahwa kurikulum dan perencanaannya (silabus) harus dilihat dari empat komponen utama yaitu: (1) tujuan; (2) isi atau materi pokok; (3) metode atau prosedur; dan (4) evaluasi.

Sehubungan dengan pengembangan KTSP, guru kewarganegaraan dalam meningkatkan kualitas pembelajaran kewarganegaraan harus memiliki hal-hal sebagai berikut: (1) Seorang Guru Pendidikan Kewarganegaraan harus mampu menyampaikan keahliannya untuk semua peserta didiknya; (2) Seorang Guru Pendidikan Kewarganegaraan harus mampu memahami bidang ilmu keahlian yang akan diajarkannya dan menghargai bagaimana pengetahuan tersebut diciptakan, diorganisasikan, dihubungkan dengan ilmu pengetahuan lainnya serta diterapkan dalam dunia nyata; (3) Seorang Guru Pendidikan Kewarganegaraan harus mampu menciptakan, memperkaya, memelihara dan menyesuaikan cara mengajarnya untuk menarik dan memelihara minat peserta;(4) Guru Pendidikan Kewarganegaraan harus mampu berkontribusi serta bekerja sama dengan teman sejawatnya tentang seluruh kegiatan yang berkaitan dengan proses belajar dan mengajar.

Dalam mengatasi kegagalan guru dalam mengimplementasikan KTSP mengakibatkan ketidakberhasilan peserta didik dalam mencapai tujuan pembelajaranleh karena itu seorang guru pendidikan kewarganegaraan harus mampu untuk menguasai kompetensi-kompetensi yang diharapkan dalam menunjang implementasi KTSP.

\section{Daftar Pustaka}

Direktorat Pendidikan Menengah Umum, 2002. Konsep Dasar Pendidikan Berorientasi Kecakapan Hidup Melalui 
Pendekatan Pendidikan Berbasis Luas dan Pelaksanaan di SMU, Jakarta: Departemen Pendidikan Nasional

Miller J.P. and M. Seller. 1985. Curriculum:persective and practise. Longman: New York and London

Meter, Gede I. 1999. Hubungan antara Kemampuan Akademik, Moivasi Kerja dan Minat Menjadi Guru dengan Profesionalisme Guru pada Sekolah Dasar Kecamatan Kubutambahan Kabupaten Buleleng. Thesis Malang. PPS UM

Mulyasa, E. 2005. Menjadi Guru Profesional Menciptakan Pembelajaran Kreatif dan Menyenangkan, Bandung: Remaja Ros Tirtahardja, Umar dan La Sula. 2000. Pengantar Pendidikan. Jakarta: Penerbit Rineka Cipta dakarya.

Nasution, S. 1989. Kurikulum dan Pengajaran. Jakarta: Bumi Aksara.

Nasution, S. 2003. Asas-asas Kurikulum. Jakarta: Bumi Aksara.

Peraturan Pemerintah Republik Indonesia Nomor 19 Tahun 2005, tentang Standar Nasional Pendidikan.

Undang-Undang no 14 Tahun 2005, tentang Guru dan Dosen sebagai Tenaga Profesi

Undang-Undang Republik Indonesia Nomor: 20 Tahun 2003, tentang Sistem Pendidikan Nasional.

Sanjaya W. 2005. Pembelajaran dan Implementasi KTSP. Jakarta:Prenada Media

Syaodih, N. S. 1997. Pengembangan Kurikulum: Teori dan Praktek. Bandung: Remaja Rosdakarya.

Tilaar, H.A.R. 1990. Pendidikan Dalam Pembangunan Nasional Menyonsong Abad XXI. Jakarta: Balai Pustaka 